\begin{tabular}{|l|l|l|}
\hline \multicolumn{2}{|c|}{ PublisherInfo } \\
\hline \hline PublisherName & $:$ & BioMed Central \\
\hline \hline PublisherLocation & $:$ & London \\
\hline \hline PublisherImprintName & $:$ & BioMed Central \\
\hline \hline
\end{tabular}

\title{
The American Fibromyalgia Syndrome Association, Inc
}

\begin{tabular}{|l|l|l||}
\hline \multicolumn{2}{|c|}{ ArticleInfo } \\
\hline \hline ArticleID & $:$ & 20 \\
\hline \hline ArticleDOI & $:$ & $10.1186 /$ ar-2000-2-webreport0014 \\
\hline \hline ArticleCitationID & $:$ & 0014 \\
\hline \hline ArticleSequenceNumber & $:$ & 16 \\
\hline \hline ArticleCategory & $:$ & Web Report \\
\hline \hline ArticleFirstPage & $:$ & 1 \\
\hline \hline ArticleLastPage & $:$ & 3 \\
\hline \hline & $:$ & RegistrationDate : 2000-7-11 \\
\hline ArticleHistory & $:$ & OnlineDate \\
\hline \hline ArticleCopyright & $:$ & Current Science Ltd2000-7-11 \\
\hline \hline ArticleGrants & $:$ & \\
\hline \hline ArticleContext & $:$ & 130752211 \\
\hline \hline
\end{tabular}




\section{Overview}

The American Fibromyalgia Syndrome Association (AFSA) is a non-profit making organisation that concentrates on promoting research, education and patient advocacy for fibromyalgia syndrome (FMS) and chronic fatigue syndrome (CFS).

The AFSA engages in the following activities:

- Funding research projects

- Sponsoring information booths at major scientific conferences

- Publishing updates on research funding activities related to FMS, CFS and other related disorders

- Selling educational material about FMS and CFS

- Distributing free brochures about the AFSA to encourage increased membership and funding

- Providing resources for patients to help them get in touch with organisations and self-help groups

- Running a phone helpline for patients and physicians.

\section{Content}

The AFSA website provides general information about FMS and CFS and acts as a promotional base for the association.

There are updates on news and activities of the organisation, and full details of all 18 research projects that have been funded by the AFSA since 1995 are listed. A grant application form is downloadable from the site.

Finally, there is a section with links to associations, publishers and websites.

\section{Evaluation}


The AFSA site is a useful "first base" for both patients suffering from FMS/CFS and scientists interested in applying for funding assistance in the field. It is a helpful and interesting resource.

\section{References}

1. http://

This PDF file was created after publication. 